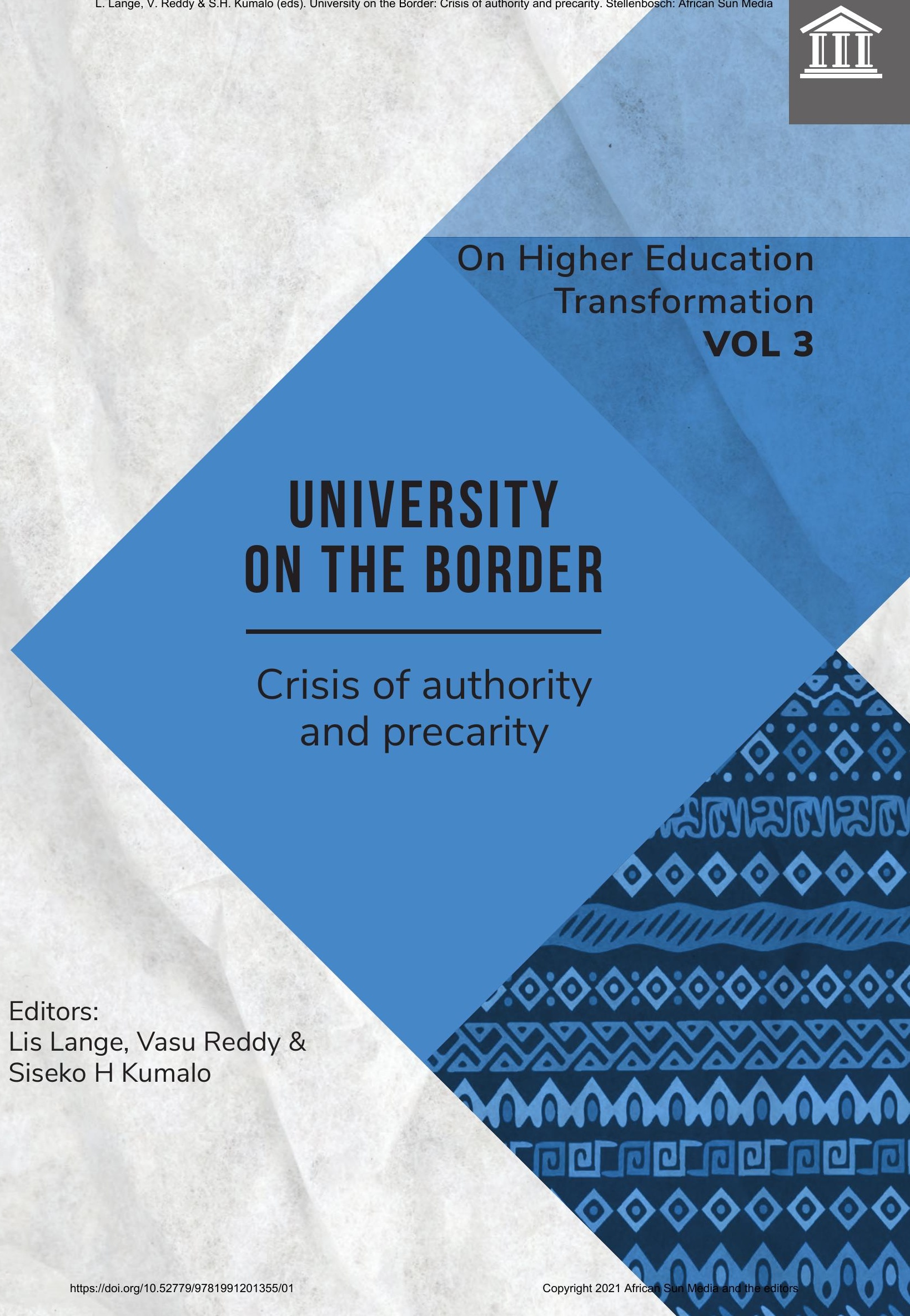




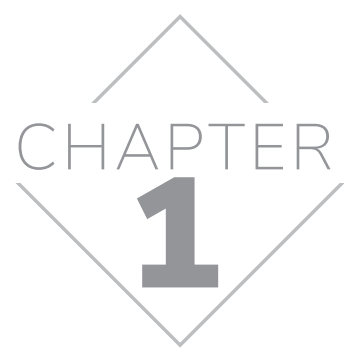

\title{
University on the Border
}

\author{
Crisis of authority
}

\author{
Lis Lange
}

\section{INTRODUCTION}

As indicated in the introduction to this volume, the \#MustFall student protest cycle in South Africa was as much at and about the University as it was for the University itself. Students confronted not only specific aspects of the University such as fees, institutional culture, bureaucratic governance, curricular orientation and socio-cultural make-up of the academic class, but they also questioned (with different degrees of clarity and explicitness across institutions) the nature and purpose of the University as a social institution. Students put forward the decolonised university in a series of dispersed and still disconnected documents and performative expressions of what can be called an alternative 'idea of the university'.

The call for the decolonisation of the University together with the demand for free education, with its implicit definition of the public university's role and purpose, were the galvanising slogans of student protest across all South African public universities' campuses for almost two years. The goal, of free decolonised higher education, remains part of a new political lexicon also adopted by university managements and the political class. Underpinning the protest there is a narrative about the defiance by excluded subjectivities of the idea of the university as a historically unified white Western institution. As in 


\section{UNIVERSITY ON THE BORDER}

the case of the Subject Philosophy in Philosophy on the Border, the established (European) grid of intelligibility represented par excellence in the institution of the University is contested, pushing the University to a space of questioning, doubt and anguish about its modes of being, doing and thinking that we call 'on the border'. For the University, being on the border necessitates the rethinking of the institution's very nature and therefore the confrontation of the existing university with the historic role of the University in the process of colonial domination and its current role in the condition of coloniality. Being on the border pushes the University to re-evaluate and re-imagine its purpose; how to respond to the demand of the new subjects that have entered its walls, and of the new society, struggling to be born in the aftermath of colonialism and apartheid.

Throughout this chapter, I use the word 'University' to refer to the idea of the university as institution and not to refer to any specific university. Although I acknowledge that \#MustFall took place at various institutional sites, my analysis focuses on historically white universities (HWUs) because the racial and decolonial dimensions of the students' confrontation with the University were the most explicit at these institutions (Ndelu, 2017:21; Maringira \& Gukurume, 2017:35-36).

In intellectual, administrative and affective ways \#MustFall's defiance of the University has thrown (mostly white) academics, managers, and alumni off course, provoking a variety of institutional crises, the majority not visible to the outsider. The students' defiance, however, was not restricted to the University as an isolated institution. It was framed as a critique of the African National Congress's (ANC) government policy blueprint and, as we will see later, as a critique of the totality of the democratic settlement and its outcomes. University management and government, in different combinations and with different intensity depending on institutional sites and the unfolding of the protest, were the enemy that the students addressed. Cameras and social media captured moments of physical and verbal rebalancing of the power relations between students and government (student demonstration at Luthuli House) and between students and management (students' interactions with vicechancellors in public spaces). The University, represented in the bodies of its senior leadership, was literally and figuratively pushed aside, questioned in its cultural centrality, social relevance and historical groundedness. In this sense, 
like the 'Subject' in Philosophy on the Border, the University is also on the border, pushed into a space of messiness, liminality, doubt and confrontation with itself (Praeg, 2018:3-4).

To those of us for whom the University has been the focus of a political and intellectual collective project, grappling with this moment, interpreting it and translating it into intellectually and morally credible modes of institutional being is part of this same commitment. In as much as this cycle of protest pertains to the broader issue of the project of the (South) African University, \#MustFall forces us to reread the foundational moments of higher education policy in South Africa and to assess these policy choices in the light of a recalibration of the achievements and failures of two decades of transformation work. This reading, however, cannot be parochial or, worse, endorse South Africa's exceptionalism. It has to be done against the genealogy of the idea of the university from Newman and von Humbolt to the theorisations that followed about the changing forms and functions of the University (Barnett, 1990; Bourdieu, 2001; Brink, 2018; Delanty, 2001; Derrida, 2004; Grosfoguel, 2013; Readings, 1996) developed over the last century. Importantly, this reflection needs to be done paying due attention to the experiences of the African University post-independence and the contemporary global expressions of dissatisfaction with the University emerging in the last years (Bhambra, Gebrial \& Nisancioglu, 2018). The purpose of this chapter is bringing to the reader the sense of messiness and aporia of the University on the border.

This chapter's framing narrative is a dialogue between Arendt, Readings, and Mamdani through the notion of 'on the border' as elaborated in the introduction. Given the orientation of this book the choice of authors might seem surprising and even contradictory. I would like to explain myself. Probably only the Catholic Church is as "Western" an institution as the University. Both, in different ways, have their authority deeply embedded in the classic tradition as their foundational point of reference. Arendt is one of the most careful thinkers of the classic tradition and its evolution in political philosophy. Following Arendt (2006), I look into the meaning of 'authority' to argue that the 'university on the border' is a university whose authority has been questioned at the core. In doing this, I map out the different elements of the critique of the University's authority, based on \#MustFall published 


\section{UNIVERSITY ON THE BORDER}

documentation. Readings' The University in Ruins was the first, and in my estimation, still the most important critique of the vacuousness of the university of excellence and of the neutrality of the University. I believe his analysis has some light to shed to understand how we have arrived at the condition of the 'university on the border'. Thus, after dealing with the concept of authority, I move to the 'idea of the university' to revisit Readings' (1996) argument about the University as an institution in ruins and try to read his argument against the grain of Mamdani's $(1993,2009,2016)$ analysis of the experience of Africa's universities, including South African universities, postindependence. Mandani is one of the African intellectuals that has engaged more constantly and deeply with the condition of the university in Africa and the issue of the production of localised knowledge, in the sense of producing theory. Finally, as explained in the introduction, the very notion of the border, as a space of doubt and opportunity is rooted in the thinking of the decolonial school (Mignolo, 2007; Quijano, 2007). I do believe that this melange of thinkers is one of the possibilities that being on the boarder affords us: neither here nor there, a space of "mestizaje" in which we engage all intellectual tools available to interpret the world in order to transform it.

My overarching argument is that the \#MustFall protest cycle has been, in profound and not yet sufficiently acknowledged ways, a defiance to the authority of the University as institution and with it to the different components of its identity, social function and organisation. I characterise this as a crisis of authority that decentres the University, pushing it to a new space of uncertainty - on the border. What should be done with it? Is there hope that something can be built on this or shall one endorse the diagnosis that suggests the \#MustFall cycle heralded the beginning of the end of the University in South Africa (Jansen, 2017)? If something can be done: what are the conditions for the emergence of the new from the 'university on the border'?

\section{ON BORDERS AND AUTHORITY}

I believe that this 'position' of 'university on the border' results from the University's crisis of authority as an institution. I see this crisis precipitated, but not caused (I will come back to this later), by the \#MustFall cycle of protest. How did this come about? What were the constitutive elements of the challenge to the University's authority? 
Before I try to answer these questions, it is necessary to lay out the meaning of authority in political philosophy. For this purpose, I use Hannah Arendt's essay, What is Authority? (2006). In answering this question, Arendt goes back to the Latin origins of the word auctoritas ('authority') and ancient Roman history. Authority is a hierarchical relationship in which the ability of one party to command and the other to obey does not rest on reason or on the power of the one who commands. The force of authority resides in its legitimacy and its accepted rightness. In turn, this authority is transmitted through tradition from those who laid the foundations, in this case, of the city of Rome, but more generally, of any polity or institution. Authority (auctoritas), Arendt explains, derives from the verb augeri ('augment'); what those in possession of authority augment is the foundation moment, the continuity of the tradition, its sacredness. Politically speaking, in the classic conception of authority, those who exercise it, do not have power (i.e., the use of violence). In fact, the use of violence is contradictory to the exercise of authority. Following on Arendt's explanation, it is possible to think of the institution of the Western university operating within most societies in a position of authority not because of what the University does or presently is, not because it has or confers power through its certification function, but because the 'idea of the university' has its roots in a millennial tradition that connects the present with foundational moments of the Western culture. Thus, through its rites and forms, the University provides continuity to its originating tradition from which it derives its authority. It is the chain of tradition that connects today's University to the founding moment of the traditional mediaeval universities and provides its legitimacy.

As Drainville aptly shows in Chapter 2, the authority of the Western University has been questioned across the globe over and over again since its very foundation. In the period 2015-2016, student protest reneged (de-authorised) the tradition that connected the Western university to (South) Africa; they metaphorically cut the chain of tradition by questioning and denouncing the very foundation of the institution, its history, symbols, knowledge, inhabitants and purpose as a continuous act of white privilege and supremacy. By occupying key spaces at the University, the students saw themselves as laying down a new foundation for the University, "in the students' terms" (\#RMF manifesto and political documents use of this phrase; Mbembe, Naidoo, Jones, Orrantia, Chari \& Van der Haak, 2015). 


\section{(DE)-AUTHORISATION AND THE REFOUNDING OF THE UNIVERSITY}

The \#MustFall students entered the historical stage after two decades of democracy and five ANC governments, calling out the democratic settlement, insufficient levels of economic advancement and the persistence of white privilege. As Booysen puts it, the narrative of these students stressed their lived experience of continuous poverty, inequality and disappointing opportunities (Booysen, 2016:27). The place where this lived experience was made more acute for this sector of the youth was the university. This situation was especially true at HWUs, where although demographic changes have rebalanced the composition of the student body, students still felt socially alienated (Nyamnjoh, 2016).

In this section, I identify different elements of the critique of the University's authority as constructed by the students to sketch the profile of the decolonised university. For this purpose, I am using the political documents of \#RMF published in 2015 and several contributions that students made, in the form of essays, poetry and photography, and a special issue of The Johannesburg Salon (JS), a publication of the Johannesburg Workshop in Theory and Criticism (Mbembe, Naidoo, Jones, Orrantia, Chari \& Van der Haak, 2015). I am aware that this analysis is inevitably limited, and that this collection should be augmented by other collectives' thoughts and contributions to the critique of the University. For the present purpose, these voices are sufficient to illustrate in a compelling enough way the range of students' defiance of the University's authority and the role of this defiance to push the University into its present position on the border. I present the items as they were written in quotation marks to distinguish them from my classification and commentary. I am not interested in this piece in engaging critically with the students thinking on the University directly. The purpose of this section is to lay out the tropes with which university leadership teams and staff had to engage and which forced the University on the border. The fact that all the material refers to UCT is, for the argument, irrelevant; UCT's name could be replaced, with small variations, by the name of any other HWU in South Africa. 


\section{The university is colonial, racist and patriarchal}

This view relates to the privilege and dominant position of white Western culture in terms of symbols, names, rituals and language, and the effect of social and emotional alienation that this produces on black students.

This alienation takes many forms: where we live, how we live, how we speak, what we say when we do speak, how we think, and, perhaps most importantly for us, what we think, speak and write about.

\#RMF Mission Statement, JS (Mbembe et al., 2015:1)

[A] racist and patriarchal society that has remained unchanged since the end of formal apartheid. \#RMF Mission Statement, JS (Mbembe et al., 2015:6)

We have begun to question the entire neo-colonial situation, whether South Africa belongs to all those who live in it and whether it is us the people that are occupying this building or whether we are realising the fact that this building and its land always belonged to the people.

\#RMF Bremner Occupation Statement, JS (Mbembe et al., 2015:9)

This dehumanisation is a violence exacted only against black people by a system that privileges whiteness.

\#RMF Mission Statement, JS (Mbembe et al., 2015:6)

The Black Imagined [Nation] is omni[potent] iAll-Present! Alive -> But constricted, by colonised cages; columns + pages. We are here to tear \& Tear. With no fear. To rip apart these frames and pages, With the fury of black rages. Unleashed. The Black Imagined[Nation]. (Poem)

The Black Imagination, JS (Mbembe et al., 2015:4)

\section{The composition of the academic body reflects white supremacy and patriarchy}

The large majority of the staff is white; males predominate and there are hardly sufficient black academics who can constitute viable role models for the new generation.

Black intellectuals were nearly suffocated at UCT for pursuing Black liberatory intellectual practices that challenged the conservatism, elitism and whiteness of the institution.

Gamedze \& Gamedze, Salon for What?, JS

(Mbembe et al., 2015:1) 


\section{UNIVERSITY ON THE BORDER}

We will be focusing on the underrepresentation of black academics, which goes hand-in-hand with our continuing research into the development of a decolonised curriculum.

\#RMF Statement read before the removal of the Rhodes statue, JS

(Mbembe et al., 2015:12)

Space is oppressive in multiple orientations (race, sex and gender) - and the University space is intrinsically organised for oppression. It was never built to teach black students or have black people be lecturers and professors. Today the institution, under white management, is taking no real measures to eradicate this spatial oppression, which isn't only physical but is fostered in the psychological.

Khumo Sebambo, Azania House as symbol of black imagination, JS

(Mbembe et al., 2015:108)

I envision a UCT where I do not have to hold only to $X X$ and $Y Y$ [names suppressed by me] as my supervisor because these are the only successful blacks that I see teaching me since there aren't that many of them to choose from anyway.

Noluvuyo Mjoli, How I envision a decolonised UCT to be like, JS (Mbembe et al., 2015:112)

Us, Black students who desire to be taught by Black female professors. Us, Black students who yearn for UCT to stop acting like Black women are flowers in revolutions and start teaching us about Mama Lillian Ngoyi, Mama Nomzamo Winnie Madikizela Mandela, Mama Charlotte Maxeke, just to name a few. Us, nappy-headed Black women with graceful knots in our rich hair, who are suffocated by the shackles of this university that celebrate white supremacy and male entitlement, though celebrating the likes of imperialists and misogynists such as Cecil John Rhodes, Jan Smuts, Leander Jameson, Barnard Beattie.

Ntebaleng Morake, Why decolonizing UCT is imperative, JS (Mbembe et al., 2015:53)

\section{The University is elitist and exclusive}

Students fear that the effect of a 'white education' or academic career might result in separating black students from their communities.

Re-evaluate the standards by which research areas are decided - from areas that are lucrative and centre whiteness, to areas that are relevant to the lives of black people locally and on the continent. 
Introduce a curriculum and research scholarship linked to social justice and the experiences of black people. \#RMF Mission Statement, JS

(Mbembe et al., 2015:8)

\section{The University curriculum is white and Western and obliterates other epistemologies}

Implement a curriculum which critically centres Africa and the subaltern. By this we mean treating African discourses as the point of departure - through addressing not only content, but languages and methodologies of education and learning - and only examining Western traditions in so far as they are relevant to our own experience.

\#RMF Mission Statement, JS

(Mbembe et al., 2015:8)

\section{Heteronormative patriarchal culture}

This view includes lack of adequate care for victims of gender-based violence; disregard for and lack of action regarding the harassment of non-genderconforming minorities; all of these are presented as objectionable and oppressive practices and values that the University are not confronting.

We've created monsters out of the boys who we once hoped would father our grandchildren. We have denied them their youth and have driven them to war with each other, teaching them that the only way to ensure that you own something, it is to show your strength and authority over it, whatever way possible, whatever the outcome it may be.

Molepo Mmamalema, Monsters, JS (Mbembe et al., 2015:46)

I want my father to account for what he's being doing to my mother, because it is wrong and cruel and violent; not to mention abusive. And I would also like to know where my father learnt this wrong, cruel, violent and abusive behaviour. Who taught my father these problematic power dynamics? There's a civil war in my house and all of us need saving! Decolonize masculinity. We cannot be anonymous anymore!

There is civil war in my house, JS (Mbembe et al., 2015:52)

The executive of the University needs to understand that anti-sexism and anti-racism are not default[-ing] values in our society, they are subversive, radical ways of being, of constantly struggling against a hegemonic system so deeply embedded in the thoughts and actions of almost all people. 


\section{UNIVERSITY ON THE BORDER}

If the University is not willing to take up the sword against the hegemonic culture of society and itself, it must stop speaking as if it is committed to values it doesn't truly understand.

oNe StAB on UCT, its orientation programmes reproduction of white patriarchy, JS (Mbembe et al., 2017:57)

\section{The governance, management and administration of the University is fully complicit with a colonial system of oppression and not to be trusted with decolonisation}

In the 20 years prior to the Rhodes Must Fall Movement the aforementioned 'deliberative processes' have been embarked on by management countless times. The presence of this statue and the continued colonised state of the university, its staff demographics, treatment of workers, institutional culture and curriculum content are clear evidence of the failure of these processes in effectively decolonising the institution.

Our existence as black people is defined by a violent system of power. The university's processes and language naturalises that colonial system.

\#RMF, April 13 Press Statement, JS (Mbembe et al., 2015:14)

\section{The University 'rational discourse' is a way of silencing black pain and constitutes an obstacle to decolonisation}

We as black people will not have our pain silenced or attacked, nor will we concede to demands that it be rationalized - all of which inevitably occur in any process of 'rational discussion' which includes the very university stakeholders at whose hands we are oppressed. The strict demarcation of legitimate discourse at [the University of Cape Town] UCT to only such rational discussion is violent and silencing to black voices - which is precisely why they have been silent until now. We will not compromise our pain.

\#RMF, Statement read at today's mass meeting before the removal of the statue, JS (Mbembe et al., 2015:12)

On a more personal note, to me the black imagination isn't a lens into an Afrofuturistic future where the black [has] inherited the earth nor is it a throwback to pre-colonial Africa where we were all Kings and Queens - the black imagination is rooted in this contemporary moment where we as black people actively seek our identities and formulate them as best as we can outside of whiteness and the questions related to subjectivity, authority, and power that, black people are not involved in forming.

Khumo Sebambo, Azania House as symbol of black imagination, JS

(Mbembe et al., 2015:109) 


\section{University knowledge and culture universalises the white experience}

This same Eurocentric reason or logic is present in most European languages that use dualisms such as black-white, male-female and physical-imaginative. In turn, these dualisms simplify the experience to be one or the other. This Western ideology constrains citizens from understanding that the physical statue has meaning, feeling and a narrative on transformation embedded in its central positioning on the campus.

Mbali Mtandela, Stagnant debates, Stagnant minds, JS (Mbembe et al., 2015:111)

The reality is that long before I was born and long after I have left. The Old Man Rhodes will still stand tall [...]

It is so intensely grating to be held in check by an environment that cannot keep [up] to speed with the consciousness of my brothers and sisters. The inertia of our Markets and Institutions alienate us from the opportunities we need to grab a hold of [...]

What should I do? Quit my job? Change my research? How am I to continue focusing on abstract issues of technology? We live in a time of heightened anxiety, and once again the framing and mission of a generation [have] begun to shine clearly through the fog of uncertainty. What was good enough yesterday, can no longer stand today. We want change now [...]

We can no longer breathe. We can no longer focus on empty dreams sold as weak inbound with White epistemologies. But, where to now?

Brian Kamanzi, Where to Now?, JS (Mbembe et al., 2015:20)

What keeping spaces like the University white does, is that it elevates white opinion of their superiority and increases their fear of black people making them more ignorant and more dangerous, might I add. As black people we outnumber white people but still find ourselves having to find ways to deal with our oppressors. WEB du Bois spoke about how power is asymmetrical in favour of whites, but knowledge of the other is asymmetrical in blacks. It is easy to test - ask black people anything about white people's lives even mundane details like how often they wash their hair, and we know. But ask white people an equally mundane question and they are usually clueless - they're so poorly versed in any grammar of blackness and it is because among other things space in both its physical and psychological manifestations [privilege] their position.

Khumo Sebambo, Azania House as a symbol of black imagination, JS

(Mbembe et al., 2025:109) 


\section{UNIVERSITY ON THE BORDER}

As can be seen from the seriatim reading of these texts, the critique of the University's authority spans its historical origins in Europe and its role as a colonial tool; its mode of thinking that universalises the Western white experience, setting it as the standard measure of quality and excellence; its medium of expression: the European languages, in this case English; its mode of expression: rational, logic, linear, publishable academic writing; its core functions (what it is taught, how it is taught and assessed; what it is researched); its governance and the standard and assumptions of its deliberative processes; its administrative and managerial processes; its culture and symbols; its distance from the (black) people outside the university; the composition of its staff and their cultural and emotional distance from black students.

The fundamental de-authorisation of the University that happened during this period, however, is of the institution itself as a disinterested curator, distributor and producer of universal (neutral) knowledge. The (South African) University is denounced in a variety of performative acts and manifestos as a (wrong) political project, or at least as part of a broader failed political project which has not delivered on its promises and does not allow black students to breathe.

Thus, the University is pushed out of its central place; its tradition broken; its authority rejected. This rejection of the University takes place while a parallel process of engagement, teaching and knowledge production happens at the University between occupying students and (black) academic staff supportive of or sympathetic to the students' cause. Was this tantamount to a re-foundation of the University, that is, the establishment of a new legitimate tradition that is acknowledged as right and therefore has authority? Before attempting to answer this question, it seems appropriate to pause in the argument to bring to bear other analyses and critique of the unsatisfactory nature of the University in the twentieth and twenty-first centuries. 


\section{THE CRISIS OF THE UNIVERSITY'S AUTHORITY IN PERSPECTIVE}

As I suggested above, \#MustFall precipitated the University's crisis as an institution, but it was not by any stretch of the imagination the single cause of the crisis. Universities in South Africa have been struggling with a structural crisis influenced as much by global trends as by the specific constraints of national higher education policy and funding (Bond, 2016; Jansen, 2003, 2004; Lange, 2017). In this section I want to introduce the salient elements of the global scene to provide a broader context to analyse the University's local crisis.

As has been often repeated, the modern University is a product of the Enlightenment's faith in the progress of reason and the rise of the nationstate in nineteenth-century Western Europe (Barnett, 1990; Brink, 2018; Delanty, 2001; Derrida, 2004; De Sousa Santos, 2005). Then the University was called to play a role in the development and transmission of national culture and support the growth of the nation through technological progress. The Humboldtian university was fundamentally a public national university responsible for the education of citizens unified through national culture. As a product of one particular branch of the Enlightenment (Mishra, 2017), the modern University ascertained European Western culture and history as the measurement of all progress and as the highest point of civilisation. During the nineteenth and twentieth centuries, these notions were embraced with local variations through the establishment of universities by colonial powers in some of the colonies (South Africa, Uganda and Nigeria) and then in the newly independent countries.

As the capitalist economy becomes globalised during the 1970s, the role of the University as the locus of production of citizens and national culture starts mutating (not without opposition and critique). If the University's predominant role were no longer to produce citizens and development but to facilitate the insertion of individuals and eventually firms in a globalised world, how should the role of the University be defined, how should its work change? More radically, was this change inevitable? Should it be resisted and if so, how? The need to adapt to this new situation in the mid-1970s and especially since the 1980 s provokes an identity crisis for the University as an 


\section{UNIVERSITY ON THE BORDER}

institution that, under pressure from dominant neoliberal governments, is subjected to a series of policy changes, affecting its internal organisation, the nature and quantum of its funding and the type of disciplines and research supported.

This situation is the backdrop to Bill Readings' remarkable book, The University in Ruins, written in the early 1990s. The book analyses three ideas that have defined the University since the eighteenth century: The Enlightenment or Kantian university had the idea of reason as its organising principle, with philosophy as the central discipline in the dispute of the faculties. The University of Reason was followed by the University of Culture influenced by German Idealism and crystalised in von Humboldt's reforms at the University of Berlin. The German university founded in the idea of national culture was constitutive to the development of the German nation-state. The dominant discipline in the University of Culture is (national) literature. These two self-realisation moments of the 'idea of the university', come to a halt in the second half of the twentieth century with the 'idea of excellence' making its appearance as the organising principle of the contemporary university. The "University of Excellence" is no longer tasked with the education of citizens, but of individuals capable of functioning in the global economy. The consequence of this shift, Readings argues, is that the role of the University in the twenty-first century will have to be re-determined because the modern university has pretty much collapsed: it is in ruins.

The main elements of Readings' diagnosis are as follows: given the changes that globalisation affected in capital reproduction and the displacement of the nation-state as an economic and political unit, the University is becoming a transnational bureaucratic corporation. In this environment, Readings continues, the notion of culture as the legitimating idea of the modern university is no longer useful. This shift requires that the University realigns its discourse about itself and replaces the idea of national culture, with its concrete, specific content in each country, for the discourse of excellence, which unlike the ideology of culture, is empty,

... it is neither true nor false. It may be unjust, but we cannot seek its injustice in terms of a regime of truth or of self-knowledge. Its rules do not carry with it an automatic political or cultural orientation.

(Readings, 1996:13) 
The political emptiness of the discourse of excellence poses new problems for the development of a critique of the University, for, Readings argues, in a University that is no longer ideological, not only is it difficult to find radical ways of disruption, but the bureaucratic discourse of excellence itself easily swallows radical disruptions. This, in his view, is a ruined institution. Faced with this situation, the most demanding and urgent question is what to do with the ruins of the University? (Readings, 1996:171).

The 'University in ruins' is, to some extent, an institution that has lost its foundational authority; its traditional knowledge organised around the discipline of literature being replaced. The 'University in ruins' has lost its raison d'être, the certitude of its role in society. The 'University in ruins', is also a 'university on the border', in the space of self-doubt, contestation and liminality.

In his analysis of the University's shifting function, Readings stops at the 1968 student movement as an emblematic moment in the critique of the University; the realisation that the role of the University is not self-evident (Readings, 1996:145); a summation that has an evident connection with the position of the 'university on the border'. I want to repeat that stop in 1968 for two reasons. First, there are interesting socio-political parallels between 1968 in France and \#MustFall in South Africa, which I believe are worth lifting; secondly, to highlight the need to look for points of reference for the understanding and theorisation of South African phenomena that are not local. Before I unpack this, it is important to acknowledge the different sociohistorical spaces. 1968 originated (but did not stay) in an imperial society; 2015 took place in a settler colonial society. 1968 started as a critique of the University and morphed into a radical critique of society, the French political system and imperialism. 2015 started off with a critique of the University as a colonial, racist space and deepened into a critique of the South African political settlement and a denunciation of the decolonial condition. Both movements entered into (different) class alliances with workers.

The kneejerk comparison between the \#MustFall students and the Soweto uprising situates the students' protest in the grand narrative of the liberation struggle that serves a narrow political appropriation of the event by political parties and at the same time takes away from the protest the critique of 


\section{UNIVERSITY ON THE BORDER}

colonialism, and of the failures of the liberation government, not to mention its global spill over.

Three sets of issues were at the centre of the students' grievances in France. First, several bureaucratic measures: Students rejected the state's attempt to modernise a mediaeval university (the University of Paris dates from the twelfth century); the attempt at establishing selective admissions as a way of dealing with the progressive massification of the university and its lack of places; and the reorganisation of the university by introducing social sciences and two-year vocational degrees. Secondly, students rejected the sociocultural discipline of the university and issues of collective identity (sexuality, gender, class, ethnicity) that figured high in their demands. Lastly, the Vietnam War and imperialism constitutes a central focus of the political protest.

Worker support through a general strike, the burning down of the Paris Stock Exchange and heavy police repression complete a political cocktail that brought the French State to its knees, even if only momentarily, as De Gaulle returned as president after an extraordinary election.

The student protest was not confined to France but was echoed in Italy, Spain, Czechoslovakia, Japan, the US, the UK, Mexico and several South American countries. In all cases, an underlying local political context was combined with anti-Vietnam War protest and broad dissatisfaction with the consumer society. In France, as much as in the rest of the centres of the revolt, 1968 signified, as Readings puts it, "the entry of the student 'body' into the sphere of the University; an entry that meant the University could no longer be understood in terms of the story of an individualist subject's passage through it” (Readings, 1996:144 - my emphasis).

The first similarity between \#MustFall and 1968 is the irruption of the student body as a collective with distinct identity-based demands, many of which defied established societal mores. Secondly, there is a critique of the capitalist system and the University's role in capitulating through the commodification of education; not in the sense that education needed to be paid for, as university education was free in France and in most of the countries where the protests took place, but in the sense of educating for the market. Thirdly, particularly 
in the case of France, the alliance with the working class is another point of confluence, except that in France the organised working class supported the students, while in South Africa, students supported disenfranchised workers. Finally, anti-American imperialism characterised the global protest.

\#MustFall was not the first time the student body entered the political scene in South Africa, but it was the first time that it involved solidarity between historically white and historically black institutions, as a result of the changing demographic profile of HWUs. It was deeply marked by identity politics with the "black body" and "black pain" taking centre stage in all the protests together with issues of gender, sexuality and ableism. True to South African history, the protest was profoundly racialised as it confronted the failure of the economic liberation of black people. \#MustFall was deeply anticapitalist, or at least vociferous against white capitalism. \#MustFall critiqued social relations inside the University; while 1968 focused on gender and sexual freedom, South African students centred their grievances on endemic forms of racism in institutional cultures. In \#MustFall and 1968, some academics supported the students; in both cases, there were parallel teach-ins where alternatives to the canon were discussed. Both moments were violent and violently repressed. Finally, and here is where the two events diverge the most: \#MustFall, especially in its \#RMF-moment, was a violent (not necessarily physical) disavowal of the knowledge taught and produced at the University because of its disregard for other epistemologies outside the Western mould. 1968 leveraged a critique of knowledge but was internal to the Western tradition. Like 1968, \#MustFall happened at a time of global discomfort with education, racism, authoritarian regimes and the notion that higher education should be paid for (Chile, US, UK, France, echoed a protest that in the time of social media went global).

Despite the dramatic changes that have taken place in the world, underlying both protests are similar questions asked across almost four decades in two very different settings: what is the relationship between the University and society, and by implication what is the relationship between the University and its students; what knowledge should the University privilege and why? 


\section{UNIVERSITY ON THE BORDER}

One last stop is necessary to completely frame \#MustFall within the debate about the University, closer to home, to look at the dispute amongst academics and intellectuals about the role of the University in post-independence Africa.

\section{RELEVANT KNOWLEDGE VERSUS UNIVERSAL KNOWLEDGE}

The University is a relatively new institution in Africa. For most of the colonial period up to the Second World War, higher education was not a priority for colonial powers. The colonial African middle class pursued university studies abroad. The oldest universities in Africa were established in South Africa towards the end of the nineteenth century (UCT, Stellenbosch University and the University of South Africa); in 1916 the colonial government created the University College of Fort Hare for blacks. In North Africa, Cairo University was founded in 1906 and the American University in Cairo in 1919; in East Africa, Uganda's Makerere College dates from 1921. After the Second World War, the British government set up the universities of Ibadan in Nigeria and Legon in Ghana. The reach of these institutions was limited to an elite and, in settler societies like South Africa, were, with the exclusion of Fort Hare, reserved for the sons of the white colonisers. With the introduction of the Extension of Universities Act of 1959, the Apartheid government created universities reserved and separated for each recognised population group (Zeleza \& Eyob, 2003). All over colonial Africa, as Mamdani (2017 TB Davies Lecture) aptly put it, the University was the first instrument of structural adjustment. It was an alien institution both in content and organisational form, with the role of the modelling of African societies along the established European path of development for its colonies (Zeleza \& Eyob, 2003). The expansion era of the University in Africa came with independence when universities were regarded as essential pieces for both nation-building and development, the two priorities of the newly independent states. The mode and focus of these priorities, however, was far from settled and gave way to a debate about the University's role in Africa that is as pertinent today as it was in the 1970s. This section deals with the decolonisation of the University in Africa (including South Africa) to complete the exploration of the idea of the university' in (South) Africa; the origins of its authority; and the importance 
of the de-authorisation of the University that took place during the \#MustFall cycle of student protest.

Mahmood Mamdani has been one of the most prominent African scholars and public intellectuals to concern himself with the problem of the University in Africa. This section draws on his extensive writing on the matter (Mamdani, 1993, 1998, 2009, 2016).

According to Mamdani, the University in post-independence Africa developed along two poles of a debate: the notion of a universal human experience (and nature) and the local response of the nationalists to this notion. At a "practical level" this debate manifested in a series of controversies about the Africanisation of the University's staff; the organisation of curriculum and departments around the disciplines or around interdisciplinary lines and the relationship between the University and society and between the University and the state (Mamdani, 2016:68-69).

According to Mamdani, the Ali Mazrui-Walter Rodney-debate at the Makerere University and the Dar es Salaam University, respectively, epitomised the tension between the conception of the University, as an institution responsible for the transmission and augmentation of knowledge about a universal human experience, and the notion of the University as responsible for the transmission and augmentation of knowledge dealing with the specificity of the local with a view to problem-solving (Mamdani, 2016:69). Variations of this apparent contradiction in the purpose of the University were already present in South Africa under apartheid. While white universities established under colonialism were imbued in the universal tradition of the Enlightenment with all the implications we have already alluded to, black universities were created to serve local needs; mostly institutions for the capacitation of homeland bureaucracies, and to respond to the needs of apartheid's separate development strategy and its variations, as it applied to the coloured and Indian populations in South Africa.

The greatest effort of higher education policy under the first democratic (ANC) government was to find a synthesis between the universal University and the locally relevant University. The post-apartheid university was to be a universal institution in that it would link itself to the Enlightenment tradition 


\section{UNIVERSITY ON THE BORDER}

and, at the same time, would be a locally relevant university that responded to the demands of the democratic transition and those of the socio-economic reconstruction and development of South Africa. This conceptual synthesis, present in the National Commission on Higher Education (1995-1996) and in the White Paper (Department of Education, 1997) that followed, was enunciated without a critique of the colonial university's role in the perpetuation of white supremacy and, especially, white privilege.

The concept of historical advantage and historical disadvantage applied respectively to white and black universities, created a tacit scale of progress at the top of which was the English colonial university and at the bottom of which was the Bantustan university. The passage between the two was approached with two different tools: individual access and mobility aided by the introduction and growth over two decades of the NSFAS budget; and a government-led restructuring of the higher education system through mergers and incorporations (Department of Education, 2001; Council on Higher Education, 2000; National Working Group, 2002) destined to counter the "geopolitical imagination of apartheid" (Department of Education, 2001: Foreword). Amongst the critiques that \#MustFall students levelled at the government is precisely the outcome of this restructuring. Interestingly, this critique has two focuses: the first one is the wisdom of specific decisions about mergers given the institutional outcomes a decade later. More specifically, this critique argues that the lack of structural socio-economic transformation in the country undermines the possibility of changing the fate of universities born out of the merger process (Vilakazi, 2017:52-53; Kujeke, 2017:84-85). The second focus of critique is the mission differentiation that the restructuring introduced, re-enacting the role of HWUs as knowledge producers while the merged institutions remain trainers of professionals and knowledge appliers (Malabela, 2017:113-114).

The decolonisation of the University in post-independence Africa implies almost by definition its Africanisation; that is, a change in the demographic composition of academics and administration; a commitment to nationbuilding and national development and a close relationship to the state (Mamdani, 2003, 2016; Zeleza \& Eyob, 2004). Neither in sub-Saharan Africa nor in South Africa did this commitment to decolonisation include 
a critical engagement with the epistemology underpinning curriculum or research choices.

Mamdani makes it clear that neither Makerere nor Dar es Salaam were oriented towards or grounded in the needs and expectations of the surrounding communities from which academics and students came. In this case, he also presents the rather negative perspective that communities had of the University (1993:12). The debate about the relationship between South Africa's universities and their communities (this being a contested and often ambiguous term in itself) was far from being solved (Hall, 2007, 2009), postapartheid. The tension between the "(white) university on the hill" and the misery of the black township is one of the tropos of the \#MustFall protest cycle as students articulated their sense of alienation (Nyamnjoh, 2016).

South African universities' experience is similar to that of sub-Saharan universities in specific aspects of the curriculum debate. The disciplinarity versus interdisciplinarity debate, that seemed to have marked the Makerere/ Dar es Salaam disputation heavily (Nyamnjoh, 2016:73-74), had its equivalent in South Africa in the programmes versus majors moment. This moment saw the introduction of area studies and the construction of programmes across departments, thanks to the modularisation of the curriculum (Ensor, 2003, 2004; Lange, 2017). In neither case did the outcome of these debates, however, result in epistemological examinations of the curricula of the kind that the \#MustFall students demanded, and when they did, as in the much-publicised Mamdani affair (1996-1998), they did not end well for the challenger to the status quo.

Recasting the struggle about and for the (South) African university thus, it is interesting to realise how much is similar north and south of the Limpopo River. One last similarity is the global context. While South Africa was 'protected' from the worst of neoliberalism and the World Bank structural adjustment of the 1980s by the apartheid regime, sub-Saharan Africa was devastated by it, African universities suffered particularly hard times: the project of the national public university was almost stillborn. South Africa's democratic transition happened when the World Bank changed its approach, but it also took place in a local context in which the democratic settlement prevented a critical interrogation of the University's past and future. The global economy's 


\section{UNIVERSITY ON THE BORDER}

imperatives marked South Africa's policy choices methodologically, administratively and politically. Imperatives that had already earmarked the (Western) university as the engine of development for the new knowledge economy. In searching for models of the new post-apartheid university, the catalogue searched was mostly that of the English-speaking university in the UK, North America and Australia (Singh, 2011).

\section{CONCLUSION}

This chapter discussed the process of the de-authorisation of the University in South Africa both as enunciated by the \#MustFall proclamations and as part of the historical critique of the University in independent Africa. I further contextualised this against the backdrop of the struggle about the purpose and nature of the Western university since its Humboldtian foundation to show that \#MustFall represents a particularly acute reformulation of the problem of the University, in general, and in Africa.

In the process of building a public University capable of serving the democratic transition, quite aside from the material and ideological difficulties of the creation of a synthesis between the universal and the local University models, what South Africa bought in the global market of ideas was, as we have seen earlier, what Readings called the "University of Excellence". However, South Africa tried to fill the emptiness of the concept (Readings, 1996) with the ideology of 'transformation' (Lange, 2004, 2020; Singh, 2004). Transformation referred to the replacement of the structures, values, processes and behaviours inherited from apartheid with those that could serve a non-racial democratic society.

In terms of the bureaucratic knowledge that underpins the "University of Excellence", the 'transformation university' has been extremely successful by doubling total enrolments in 20 years; doubling the proportion of African students in enrolments; improving completion rates and graduations; extending financial aid year by year, increasing access to higher education for the poor. The University's crisis of authority, however, comes from a different place. It comes from having avoided the questions to start a different conversation about the curation, transmission and knowledge production in the decolonial situation: What knowledge? Whose knowledge? What/ 
who gets privileged? Whose interest dominates? (UCT Curriculum Working Group, 2018).

The \#MustFall students very formulation of these questions and their many administrative corollaries, and particularly their answers, have thrown the South African university off balance. The University is on the border: neither Western reason nor culture are acceptable organising principles in themselves; the post-independence project of the African University has by all accounts failed north and south of the Limpopo. The \#MustFall students revolted against the intrinsic limits of the transformation university. 'University on the border' has the double consciousness of the contradiction of its identity, the struggles between tradition and the de-authorisation of the tradition; global and local demands; past and future. The 'university on the border' has selfdoubt as its constitutive principle. As the negation of the self-assurance of the Western knowledge project, on the border seems a hopeful place from where to build. 


\section{REFERENCES}

Alfaisal, H.S. 2017. Border Reading: Epistemic Reading and the Worlding of Postcolonialism. Transmodernity: Journal of Peripheral Cultural Production of the Luso-Hispanic World, 7(2):41-54.

Arendt, H. 2006. 1954. What is Authority? In: H. Arendt (ed.). Between Past and Future: Eight Exercises in Political Thought. New York: Penguin. 91-141.

Badat, S. 2015. Deciphering the meanings and explaining the South African higher education student protests of 2015-16. Pax Academica: African Journal of Academic Freedom, 1-2:71-106.

Barnett, R. 1990. The Idea of Higher Education. Buckingham: The Society for Research into Higher Education.

Bhambra, G., Gebrial, D. \& Nisancioglu, K. 2018. Decolonising the University. London: Pluto Press.

Bond, P. 2016. To won free education, fossilised neoliberalism must fall. In: S. Booysen (ed.). Fees Must Fall: Student Revolt, Decolonisation and Governance in South Africa. Johannesburg: Wits University Press. 192-213. https://doi. org/10.18772/22016109858.14

Booysen, S. 2016. Two weeks in October: Changing governance in South Africa. In: S. Booysen (ed.). Fees Must Fall: Student Revolt, Decolonisation and Governance in South Africa. Johannesburg: Wits University Press. 21-52. https://doi. org/10.18772/22016109858

Boughey, C. \& McKenna, S. 2016. Academic Literacy and the Decontextualised Learner. Critical Studies in Teaching and Learning, 4(2):1-9. https://doi.org/ 10.14426/cristal.v4i2.80

Bourdieu, P. 2001. Homo Academicus. Oxford: Polity.
Brink, C. 2018. The Soul of the University. Bristol: Bristol University Press.

Chikane, R. 2018. Breaking a Rainbow, Building a Nation: The Politics Behind \#MustFall Movements. Johannesburg: Picador Africa.

Council on Higher Education. 2000. Towards a New Higher Education Landscape: Meeting the Equity, Quality and Social Development Imperatives of South Africa in the 21st Century. Pretoria: CHE.

Delanty, G. 2001. Challenging Knowledge: The University in the Knowledge Society. Buckingham: The Society for Research into Higher Education.

Department of Education. 1997. Education White Paper 3: A Programme for the Transformation of Higher Education. Pretoria: DoE. https://bit.ly/3okg4xe

Department of Education. 2001. National Plan for Higher Education. Pretoria: DoE.

Derrida, J. 2004. Eyes of the University. Redwood City, California: Stanford University Press.

De Sousa Santos, B. 2005a. La Universidad en el Siglo XXI: Para Una Reforma Democrática y emancipadora de la Universidad ['The University in the XXI Century: For a Democratic and Emancipatory Reform of the University']. Buenos Aires: Mino y Davila.

De Sousa, Santos B. 2005b. El milenio huérfano: Ensayos para una nueva cultura política ['The Orphan Millennium: Essays for a New Political Culture']. Madrid: Trotta.

De Sousa Santos, B. 2014. Epistemologies of the South:Justice against Epistemicide. London: Paradigm Publishers. 
Dussell, E. 2011. From Critical Theory to the Philosophy of Liberation: Some Themes for Dialogue. Transmodernity, 1(2):16-46.

Ensor, P. 2003. The national qualifications framework and higher education in South Africa: Some epistemological issues. Journal of Education and Work, 16(3):325-346. https://doi. org/10.1080/1363908032000099476

Ensor, P. 2004. Contesting discourses in higher education curriculum restructuring in South Africa. Higher Education, 48(3):339-359. https://doi. org/10.1023/B:HIGH.0000035544.9 6309.f1

Grosfoguel, R. 2007. The Epistemic Decolonial Turn. Cultural Studies, 21(2-3):211-223. https://doi.org/ 10.1080/09502380601162514

Grosfoguel, R. 2011. Decolonizing PostColonial Studies and Paradigms of Political-Economy: Transmodernity, Decolonial Thinking, and Global Coloniality. Transmodernity, 1(1).

Grosfoguel, R. 2013. The Structure of Knowledge in Westernized Universities. Epistemic Racism/Sexism and the Four Genocides/Epistemicides of the Long 16th Century. Human Architecture: Journal of the Sociology of SelfKnowledge, XI(1):73-90.

Hall, M. 2007. Overview of 'The University in Africa' Symposium: Transformation and Continuity in the University in Africa. Social Dynamics, 33(1):181-198. https://doi. org/10.1080/02533950708628748

Hall, M. 2009. New Knowledge and the University. Anthropology Southern Africa, 32(1\&2):9-76. https://doi.org/ $10.1080 / 23323256.2009 .11499980$
Jansen, J. 2003. Mergers in South African higher education: theorising change in transitional contexts. Politikon, 30(1):27-50. https://doi.org/10.10 80/0258934032000073897 [17 February 2017].

Jansen, J. 2004. Race and education after ten years: conversations. Perspectives in Education, 22(1):117-128.

Jansen, J. 2017. As by Fire: The End of the South African University, Cape Town: Tafelberg.

Kujeke, M. 2017. Violence and \#FeesMustFall Movement at the University of KwaZulu-Natal. In: M. Langa (ed.). \#Hashtag. An analysis of the \#FeesMustFall Movement at South African Universities. Johannesburg: Centre for the Study of Violence and Reconciliation. 83-95.

Langa, M. (ed.). 2017. \#Hashtag: An Analysis of the \#FeesMustFall Movement at South African Universities. Johannesburg: Centre for the Study of Violence and Reconciliation.

Lange, L. 2004. Symbolic Policy and Performativity: South Africa's higher education between the devil and the deep blue sea. Kagisano, 4:21-38.

Lange, L. 2017. 20 Years Higher Education Curriculum Policy in South Africa. Journal of Education, 68:28-57.

Lange, L. 2020. Transformation Revisited: Twenty Years of Higher Education Policy in South Africa. In: I. Rensburg, S. Motala \& M. Cross (eds.). 2020. Transforming Universities in South Africa. Pathways in Higher Education Reform. Leiden: Brill. 39-59. https://doi. org/10.1163/9789004437043_003 
Leibowitz, B. 2017. Cognitive justice and the higher education curriculum. Journal of Education, 68:93-111. http://joe.ukzn.ac.za

Luckett, K. 2016. Curriculum contestation in a post-colonial context: a view from the South. Teaching in Higher Education, 21(4):415-428. https://doi. org/10.1080/13562517.2016.1155547

Luckett, K. \& Naicker, V. 2016. Responding to misrecognition from a (post)/colonial university. Critical Studies in Education, 60(2):187-204. https://doi.org/10.1080/ 17508487.2016.1234495

Luescher, T.M. 2016. Student Representation in a Context of Democratisation and Massification in Africa: Analytical Approaches, Theoretical Perspectives and \#RhodesMustFall. In: T.M. Luescher, M. Klemenčič \& J.O. Jowi (eds.). Student Politics in Africa: Representation and Activism. Oxford: African Books Collective. https://doi.org/10.47622/ 978-1-928331-22-3

Malabela, M. 2017. We are already enjoying free education: Protest at the University of Limpopo (Turfloop). In: M. Langa (ed.). \#Hashtag. An analysis of the \#FeesMustFall Movement at South African Universities. Johannesburg: Centre for the Study of Violence and Reconciliation. 108-120.

Maldonado-Torres, N. 2007. On the Coloniality of Being. Cultural Studies, 21(2):240-270. https://doi. org/10.1080/09502380601162548 [6 May 2007].

Maldonado-Torres, N. 2011. Thinking through the Decolonial Turn: Postcontinental Interventions in Theory, Philosophy, and Critique - An Introduction. Transmodernity, 1(2):1-13.
Maldonado-Torres, N. 2016. Outline of Ten Theses on Coloniality and Decoloniality. Frantz Fanon Foundation, October 23. https://bit.ly/3ohUjy5

Mamdani, M. 1993. University Crisis and Reform: A Reflection on the African Experience. Review of African Political Economy: Setting an Agenda for Change in Africa, 58:7-19. https://doi. org/10.1080/03056249308704016

Mamdani, M. 1998a. Is African studies to be turned into a new home for Bantu education at UCT? Social Dynamics, 24(2):63-75. https://doi. org/10.1080/02533959808458649

Mamdani, M. 1998b. Teaching Africa at the post-apartheid University of Cape Town: A critical view of the 'introduction to Africa' core course in the social science and humanities faculty's foundation semester, 1998. Social Dynamics, 24(2):1-32. https:// doi.org/10.1080/02533959808458646

Mamdani, M. 2009. Scholars in the Marketplace. The Dilemmas of NeoLiberal Reform at Makerere University, 1989-2005. Cape Town: HSRC Press.

Mamdani, M. 2016. Between the public intellectual and the scholar: decolonization and some postindependence initiatives in African higher education. Inter-Asia Cultural Studies, 17(1):68-83. https://doi.org/ 10.1080/14649373.2016.1140260

Mamdani, M. 2017. TB Davies Academic Freedom Lecture, UCT, August 23. https://www.youtube.com/ watch?v=vKFAYXf05NO

Maringira, G. \& Gukurume, S. 2017. Being Black in \#FeesMust Fall and \#FreeDecolonisedEducation: Student Protests in the University of the Western Cape. In: M. Langa (ed.). 
\#Hashtag. An analysis of the \#FeesMustFall Movement at South African Universities. Johannesburg: Centre for the Study of Violence and Reconciliation. 33-47.

Mbembe, A. 2015. Decolonizing Knowledge and the Question of the Archive. https://bit.ly/3fmHOO6

Mbembe, A. 2016. Decolonizing the University: New Directions. Arts \& Humanities in Higher Education, 15(1):29-45. https://doi. org/10.1177/1474022215618513

Mbembe, A., Naidoo, L-A., Jones, M., Orrantia, J., Chari, S. \& Van der Haak, B. 2015. Rhodes Must Fall Statements: UCT Rhodes Must Fall Mission Statement. The Johannesburg Salon, 9:6. Johannesburg: Johannesburg Workshop in Theory and Criticism/University of the Witwatersrand. https://bit.ly/ 2SLKIUx [28 February 2017].

Mignolo, W. 2007. Introduction. Cultural Studies, 21(2-3):155-167. https://doi. org/10.1080/09502380601162498

Mishra, P. 2017. Age of Anger: A History of the Present. New York: Farrar, Strauss and Giroux.

Naidoo, L. 2016. The 15th Ruth First Lecture (full text). Mail \& Guardian, August 17.

National Working Group. 2001. The Restructuring of the Higher Education System in South Africa: Report of the National Working Group to the Minister of Education. Government Gazette No. 23549 (Appendix 3 of the Notice), 21 June 2002. Pretoria: Government Printing Works. 56.

Ndlovu-Gatsheni, S. 2013. Coloniality of Power in Postcolonial Africa. Dakar: Codesria (Council for the Development of Social Science Research in Africa).
Ndelu, S. 2017. 'A Rebellion of the Poor': Fallism at the Cape Peninsula University of Technology. In: M. Langa (ed.). \#Hashtag. An analysis of the \#FeesMustFall Movement at South African Universities. Johannesburg: Centre for the Study of Violence and Reconciliation. 13-32.

Nyamnjoh, F.B. 2016. \#RhodesMustFall: Nibbling at resilient colonialism. Bamenda, Cameroon: Langaa RPCIG. https://doi.org/10.2307/j.ctvmd84n8

Quijano, A. 2007. Coloniality and Modernity/Rationality. Cultural Studies, 21(2-3):168-178. https://doi. org/10.1080/09502380601164353

Ray, M. 2016. Free Fall: Why South African Universities are in a Race against Time. Johannesburg: Bookstorm.

Readings, B. 1996. The University in Ruins. Cambridge, Massachusetts: Harvard University Press.

Singh, M. 2004. Bundy Blues: Contradictions and Choices in South African Higher Education. Kagisano, 4:64-75.

Singh, M. 2011. Global toolboxes, local toolmaking: the contradictions of external evaluation in South African higher education reform. In: R. King, S. Marginson \& R. Naidoo (eds.). Handbook on Globalization and Higher Education. Cheltenham: Edward Elgar.

Soudien, C. 2010. Grasping the nettle? South African higher education and its transformative imperatives. South African Journal of Higher Education, 24(5):881-896.

Swartz, S., Mahali, A., Moletsane, R., Arongundade, E., Khalema, N., Cooper, A. \& Groenewald, C. 2018. Studying while Black. Race, Education and Emancipation in South African Universities. Cape Town: HSRC Press. 


\section{UNIVERSITY ON THE BORDER}

Vilakazi, M. 2017. Twshane University of Technology: Soshanguve Campus Protests Cannot be Reduces to \#FeesMustFall. In: M. Langa (ed.). \#Hashtag. An analysis of the \#FeesMustFall Movement at South
African Universities. Johannesburg: Centre for the Study of Violence and Reconciliation. 49-57.

Zeleza, P. \& Eyob, D. (eds.). 2003.

Encyclopedia of Twentieth-Century African History. London: Routledge. 